\title{
Dr. Ramesh Sabanadesan MBBS(Col), MS(Col), FRCS(Edinburgh) An Appreciation
}

The surgical community of Sri Lanka was shocked and saddened by unexpected news on the eve of 1 st November 2011. It was the sudden demise of Dr. Ramesh Sabanadesan, Consultant Gastro Intestinal Surgeon of TH Karapitiya, of a heart attack he suffered that morning. Ramesh was so young and full of life, my mind refused to accept the painful truth that he is no more. However the cold hands of death had gripped his life and he had already bid a silent farewell to all of us.

My earliest recollection of Ramesh takes me way back to 1983 , to the familiar surroundings of the Colombo Medical School, where we were batch mates. Friendly and gentle in nature, tall and lean in physique, he was well liked by all. Ramesh could be located with certainty, at any given time in the vicinity of the common rooms, where he revelled in the life of a medical student. He patronized the pool table, the table tennis table and the carom boards, with a sheer sense of glee. He had so much of time at his disposal for almost everything a medical student could possibly do. Neither the stress of studying medicine nor life in general seemed to have bothered him in any way. Being an ardent cricket fan, he used to spend many evenings at the Singhalese Sports Club, watching his favourite game, surrounded by an equally enthusiastic bunch of friends.

Ramesh lived his medical student days to the full, while excelling in his studies with ease. The usual five year medical course was extended to a painful and long drawn eight years for us due to the volatile political situation prevailing in the country at that time. We had to wait till the end of 1991 to sit our final MBBS. Ramesh came out with flying colours, obtaining a distinction in Medicine with a second class honors degree.

He served as an intern house officer, in the General Hospital Colombo in 1992, in Medicine and General Surgery. Being gentle and compassionate, he had numerous friends among all categories of staff. May it be another doctor, nurse, a labourer or a clerk from the office, he would have helped them in some way or the other. He was at ease among any crowd and in any circumstance.
He went on to realize his lifelong dream of becoming a surgeon by passing the MS part 1 examination in July 1994 and the MS part 2 examination in October 1998. $\mathrm{He}$ did his registrarship in various surgical departments in the Colombo General Hospital, and his Senior Registrarship at the North Colombo teaching hospital Ragama and later in General Hospital Colombo.

Ramesh chose Colorectal surgery as his specialty, with special interest in Laparoscopic Surgery. He went to U.K. in January 2002 for his foreign training, where he got himself trained in Colorectal and Laparoscopic surgery. He passed the FRCS Edinburgh examination to become a fellow of the Royal College of Surgeons Edinburgh.

He returned to Sri Lanka in 2006 and was posted to General Hospital Ampara, where he served the local community with much dedication and commitment. He was dearly loved both by the people and staff at the Ampara hospital for his unassuming ways and compassion and devotion towards his patients. Ramesh later assumed duties as the Gastro Intestinal Surgeon at Teaching Hospital Karapitiya, Galle, where he served until his sudden and untimely death.

He leaves behind his widowed mother, his sister and brother-in law with their three children living in U.K.

Ramesh was a simple, honest gentleman and a surgeon who showed much dedication to his patients and love affection and care to his friends and family. In his rather short journey of forty seven years, he touched the hearts of many people who were fortunate enough to associate him, in his own special way. His was an uncomplicated life, light footed and gentle.

Farewell dear friend. May the earth settle on you lightly.

\author{
Dr. Hasanjaya Gunawardhana. \\ MBBS (Col), MS (Col), FRCS (Edinburgh), FRCS \\ (Glasgow) \\ Consultant Gastro Intestinal Surgeon, \\ North Colombo Teaching Hospital, Ragama.
}

